\title{
The Ambiguous Meaning of the Ethical Issue in a Context of NPM Reforms: Insights from the OECD, Canada and France
}

Thomas Scapin

\begin{abstract}
An important interest in public-administration ethics has been expressed in OECD member states since the 1990s in reaction to the development of New Public Management (NPM) reforms. However, the meanings attached to the ethical issue in a context of managerial modernization remain ambiguous depending on the country and/or time period studied. Therefore, this article aims at underlining the main characteristics of administrative ethics thanks to the creation of a theoretical concept which summarizes them. The latter can also serve as an analytical grid to engage in further research and especially comparisons between varying national cases.

For that purpose, the analysis is divided in two parts and draws insights from the Organisation for Economic Cooperation and Development, Canada and France, through a review of major official reports and a series of interviews with public officials and experts in charge of these questions. First of all, it concentrates on the OECD's historical activities on public-sector ethics in order to devise a theoretical concept of administrative ethics. The utility and relevance of this concept is then tested while being implemented to compare the Canadian and French governments' overall interest in ethics in their process of public-management reform.

The article distinguishes two key dimensions of public-administration ethics, namely the managerial and normative ones, which are strongly intertwined. On the one hand, the managerial dimension focuses on the management of civil servants' daily behaviors and combines the compliance-based and integrity-based approaches to govern conducts in public administration. On the other hand, the normative dimension refers to the normative framework incorporating the core principles and values which define civil servants' professional identities and guide their specific missions and goals within the democratic system.
\end{abstract}


The historical comparison of major trends in terms of administrative ethics in Canada and France shows, finally, that, despite national characteristics, the two countries have tended progressively to deal with the ethical issue in a more comprehensive way. They are trying to take into account, for example, problems due to conflicts of public values and combine compliance-based and integrity-based instruments of ethics management. These evolutions shed light more generally on the movement of hybridization, incorporating elements from traditional public administration and New Public Management, which seems to develop in both states.

\section{Keywords}

ethics; public administration; New Public Management; OECD; Canada; France.

\section{Introduction}

Ethics is regarded as one key pillar (OECD. Public Governance and Territorial Development Directorate 2009) of public administration and governance as a whole by the Organisation for Economic Cooperation and Development (OECD). Some of its member states have made efforts recently to update their policies and measures in this area. One of the latest examples was the adoption by the French National Assembly in October 2015 of a draft law related to civil servants' ethics, rights and obligations (France. Assemblé Nationale 2015). Similarly, a new version of the Values and Ethics Code for the Public Sector was issued in 2011 by the Government of Canada.

If there has been growing interest in public-administration ethics in recent years, it must be kept in mind that it was also a major reason for the establishment of a professional and neutral civil service at the end of the $19^{\text {th }}$ century and the beginning of the $20^{\text {th }}$ century in most Western countries. ${ }^{1}$ Indeed, problems of patronage and corruption caused by the close proximity between political leaders and civil servants at the time paved the way for structural changes, like the strict separation between politics and administration, merit-based recruitment, hierarchy as well as command and control systems. Unlike these evolutions, the analysis of administrative ethics has developed slowly throughout the last century. It was not before the 1970s in the United States that a specialized and significant field of research emerged in the wake of John Rohr's seminal work (1978) before progressively extending to the rest of the world (Cooper 2001).

A renewed concern for this central issue has been strongly expressed among OECD states since the 1990s in reaction to the development of managerial reforms usually inspired by the New Public Management (NPM). The latter does not refer to a coherent reform model but rather to a "set of broadly similar administrative

1 For example, the Pendleton Civil Service Reform Act of 1883 in the United States or the Civil Service Acts of 1908 and 1918 in Canada. 
doctrines" (Hood 1991, 3) which advocates the introduction within public administration of market-type mechanisms and private-sector management tools in order to improve its economic performance (Merrien 1999).

In spite of differences in the scope and ways public-management reforms have been implemented in each national case, they have almost unanimously raised questions about their compatibility with public sector's philosophy and functioning. It has been especially true among public-administration scholars debating on "the impact of NPM-reforms on the ethics of public servants", known as the "NPMethics literature" (Maesschalck 2004, 466). Diverse types of works have emerged in relation to these debates. Some deal, for example, with the empirical assessment of supposed increasing ethical violations (Kolthoff et al. 2007; Kolthoff 2007) or conflicts between different public values (De Graaf and Van Der Wal 2010; De Graaf and Paanakker 2015).

A big stream of research in the United States and Europe has also focused on "ethics management" (Menzel 2001) strategies. Proponents of this approach have strived to complement and compensate for possible corruption and ethics risks caused by managerial innovations but without undermining them (Maesschalck $2004,2005)$. In a similar vein, but from a different theoretical background, a research program on applied ethics to organizations (léthique organisationelle) has developed in the French-Canadian province of Québec since the early 2000s. It has sought to associate ethics, understood as a regulation mode based on civil servants' autonomous ethical judgment, with the managerial modernization of public administration (Boisvert et al. 2003; Boisvert 2011a).

Several remarks can be made after briefly reviewing this broad literature. First, there is a relative lack of comprehensiveness in the analysis of administrative ethics. Although a more comprehensive book was published recently (Huberts 2014), specialists usually tend to focus on one separate aspect of this issue. For example, the ethics-management approach often concentrates on implementation problems and overlooks reflections about conflicts between different public values. Second, research in the field often remains abstract and decontextualized. It does not explain how and why the ethics of civil servants has been perceived and tackled in various ways over time and space. While many analyses compare evolutions of the overall public-management movement (Pollitt and Bouckaert 2011) as well as national trajectories of reforms (Kickert 2008; Ongaro 2009), there are no similar attempts regarding administrative ethics, even though some specialists are well aware of these limits (De Graaf and Van Der Wal 2009).

One could ask, for example: how has public-administration ethics been understood precisely in OECD states depending on specific administrative traditions? Have Anglo-American countries and Continental European countries shared the same concerns and applied the same types of measures since the 1990s? How has ethics influenced the development of administrative reforms, and the other way 
around? Is administrative ethics considered differently in the context of NPM or public governance? In other words, there is still a lot of confusion about the meanings attached to the ethical issue since the beginning of public administration's managerial reform process in OECD countries.

In order to deal with this problem, the aim of this article is to devise a theoretical concept of administrative ethics which outlines the key characteristics of this phenomenon. One major reason for the creation of such a concept, regarded as a kind of Weberian ideal type (see Weber 1965, 106-168), is to get an analytical grid making it possible to engage in further research. This tool would be especially useful to make not only in-depth studies of national situations but also comparisons between varying countries. Indeed, there are many methodological biases associated with comparison. One serious shortcoming is, for instance, the idea that too differing national cases are incomparable (Hassenteufel 2005). But there are also practical limits, e.g. problems of translation between languages. A good example related to our topic is the French word éthique, whose meaning tends to go far beyond "ethics" in English. The latter is then usually translated into French by déontologie, when applied to public administration. Therefore, the theoretical concept of administrative ethics presented in this article intends to overcome some of these difficulties.

This study draws insights from the OECD, Canada and France but without pretending to be exhaustive. For clarity's sake, it is divided into two parts. On the one hand, it concentrates on the OECD's long-lasting expertise (Boisvert 2011b, 11-52) concerning public ethics and integrity ${ }^{2}$ in order to be able to make general conclusions synthesized in the concept. It is assumed here that the work done by this organization ${ }^{3}$ may be considered a representative example of the core evolutions in administrative ethics for the past twenty years. Indeed, the OECD was the first international organization to dedicate activities to this question in the 1990s and has produced since then an impressive amount of reports, models, standards and recommendations based on systematic research and comparisons between its member states. That being said, one must still bear in mind that the OECD's work on ethics is not without limits. For example, it tends sometimes to neglect the individual public servant and the cultural dimension while concentrating mainly on rules and regulations (Lynch and Lynch 2011,254). And yet, despite differences between OECD countries and possible biases, it is regarded here as a relevant enough overview of big trends in this matter.

On the other hand, the usefulness and relevance of the concept is tested through its implementation as an analytical grid to compare the Canadian and French governments' overall interest in ethics in their historical process of manage-

2 No specific distinction is made between the terms "ethics" and "integrity" in this article. For more details on the different uses of these concepts, see Cox 2009.

3 The analysis focuses exclusively on activities realized by the Public Management (PUMA) and Public Governance (GOV) committees and services (see explanations below). 
ment reform. The choice of these two countries is due to their differences in terms of political system and administrative culture ${ }^{4}$ as well as their apparent opposition regarding the development of administrative ethics. Canada was among the first OECD states in the mid-1990s to deal with the ethical issue in the federal public service, whereas France was at the time more reluctant to tackle civil servants' ethics but has proved to be more willing to fill the gap since the late 2000s.

Concerning the methodology and data collected, the analysis for each case relies mainly on a review of major public official reports. Some archive documents ${ }^{5}$ from the OECD's public management and governance services and committees are also analyzed. Besides, this article draws directly on responses from semi-structured interviews carried out in person from December 2013 to June 2015 with: three former and current OECD officials (two of them being heads of a directorate or a division and the other a consultant for the Organisation), two Canadian top executives in charge of values and ethics in the federal civil service and one French public servant working on state modernization and ethics. For confidentiality reasons, all interviews are left anonymous throughout the article and referenced with a code associating each case to a number.

\section{A conceptualization of the main features of public administration ethics: insights from the OECD}

\subsection{The OECD's work on public ethics: from ethics management to public values}

As already mentioned, the OECD is considered a key reference in the fight against corruption and the promotion of ethics in the public sector. More precisely, it is the Public Management (PUMA) Committee supported by its corresponding service ${ }^{6}$ which started to turn its attention to these issues in the first half of the 1990s. It is important to recall that PUMA was at the time devoting most of its activities to putting forward public-management ideas and standards (Pal 2009, 2012). Indeed, the committee drew directly on NPM practices like privatization, deregulation, devolution of power through empowerment and results-based management (OECD

4 Each country represents a different political system, a Westminster parliamentary versus a SemiPresidential regime, but also a broad administrative tradition within the OECD area, i.e. an Anglo-American versus a Continental European system.

5 All documents cited are available for consultation at the Centre for External Researchers, the OECD Library and Archives, OECD Headquarters, Paris.

6 As a reminder, the OECD has a threefold structure: at the top, the Council gathers ambassadors of the member states who set the broad orientations and make decisions about the existence per se of the Organisation. There is then a system of committees made up of national representatives and generally specialized in the policy sector, with smaller working groups and networks focusing on a theme. The third and final organ is the Secretariat led by the Secretary General and composed of administrative services (directorates) dedicated to support the work done by the committees. 
1995), which had been developed since the late 1970s primarily in the Anglo-American countries before extending to the rest of Europe.

The committee sought nonetheless during this period to balance its managerial orientation with "a more explicit reference to ethics and shared values in the public service and the importance of enhancing professional standards and democratic principles" (OECD. Public Management Service 1994, 4). Several member states had indeed begun progressively to express concerns for the ethical issue, which was officially recognized in 1995 during a meeting of the network of Senior Officials from Centres of Government. The participants insisted on the "apparent decline in confidence in government ... with corresponding negative implications for the legitimacy of government and its institutions" (OECD. Public Management Service $1995,2)$ due to an increase in scandals within the public sector. The decision to start full-time activities about the ethics of public officials was thus taken explicitly in reaction to "the down side" (interviewee OECD2) of managerial reforms as clearly stated by this former consultant within the PUMA service:

\section{[Member states] were at that time very much into public man- agement. And there was a concern that if you gave too much dis- cretion to managers, this would raise ethical issues (interviewee OECD3).}

The first initiative in the field was thus to review measures of ethics management in nine self-selected countries whose results were published in 1996 in the report entitled Ethics in the Public Service: Current Issues and Practices. It is worth underlining briefly the main features of the first ever OECD report on public ethics. First of all, it privileged a managerial and "institutional" (interviewee OECD1) approach to ethics defined as "the rules that translate characteristics, ideals or ethos into everyday practice" (OECD 1996, 14). It also provided an "ethics infrastructure" consisting of "tools and processes to regulate against undesirable behavior and to provide incentives to good conduct" (OECD 1996, 8) with the view to "serving three functions: control, guidance, and management" (OECD 1996, 27).

This framework relied more precisely on the combination of two broad strategies to manage ethics in the public service. On the one hand, the "low-road" or "compliance-based approach" put the emphasis on "strict compliance with administrative procedures and detailed rules (often codified in legislation) which define what public servants should do and how" (OECD 1996, 59). On the other hand, the "high-road" or "integrity-based approach" insisted on "encouraging good behavior rather than policing and punishing errors or bad behavior" (OECD 1996, 59). It focused on achieving ends, especially thanks to values statements, non-binding codes of ethics, training for ethical decision-making etc. Given the development of public management, the OECD has tended to put forward the integrity-based approach regarded as more compatible with the results-based philosophy and organizational model of NPM reforms. 
It is important to note the central reference made to the ethics-management knowledge which served as the main background for the report. For example, the "low-road" and "high-road" approaches were originally presented by Rohr in his seminal book (1978). The main reason explaining this influence lies in the existence of a close collaboration at the time between PUMA officials and several academic and professional experts in administrative ethics (interviewee OECD3). One of them, for example, was the national representative of the United Stated to the OECD while being also "Special Assistant to the Director of the US Office of Government Ethics" (OECD. Public Management Service 1997, 2) and pointed out the need for "realigning ethics systems to fit the new models of public administration" (OECD. Public Management Service 1997, 6).

Nevertheless, this attempt to link new working practices in the public sector with ethical requirements was not limited to the institutional aspect. More fundamentally, PUMA highlighted the necessity to reconcile the main goals of public management, namely "the 'three E's', economy, efficiency and effectiveness" with the growing priority attached to "a fourth 'E': ethics" (OECD 1996, 9). This statement is particularly interesting insofar as it shows a certain ambiguity about the meaning of the term "ethics" in the report. Unlike the first managerial definition cited above, the focus here seems to be more on the content of ethics understood as a specific goal or value opposed to the three others.

The PUMA committee has progressively devoted more and more attention in the following documents to public-sector values. A good example of this increasing emphasis is found in its review of the implementation by member countries of the Recommendation on Improving Ethical Conduct in the Public Sector, adopted in 1998 by the OECD Council. The report stressed the need to identify "core values [which] should provide a solid basis for daily operations in the public service" and the fact that "impartiality, legality and integrity are the distinct characteristics of the public service" (OECD 2000, 12) in OECD countries. More importantly, it claimed that public ethics was "a keystone of good governance" (OECD 2000, 9).

The link made then between ethics, especially its normative content, and good governance must be outlined. Indeed, the work done on public ethics has been an "integral part" (interviewee OECD2) of the development towards good governance at the OECD. It has even had an impact on a broader scale in the way to conceive this new perspective according to a former consultant:

I think there was a contribution towards, you know, discussion about governance. And the whole issue of the terminology of governance came from the World Bank. But it was seen much more, just simply as a simple decision-making mechanism. The whole idea of the ethos, the values, the ethical principles underlying, I think the OECD had a contribution (interviewee OECD3). 
This shift finally triggered the demise of PUMA, replaced in the early 2000s by the Public Governance committee and directorate (GOV). More importantly, the more "systemic approach" (interviewee OECD1) associated with good governance has also influenced the international organization's program on the ethical issue because it has led to frame it in terms of "integrity" since the mid-2000s.

One of the last significant publications on the subject defines public integrity as "the application of generally accepted public values and norms in the daily practice of public sector organizations" (OECD. Public Governance and Territorial Development Directorate 2009, 9). This definition is interesting insofar as it shows a synthesis between the more explicit reference to public values and the managerial orientation always favored by the OECD. The new "integrity framework" appears also to be an updated and more comprehensive version of the former ethics infrastructure. It strives to overcome "the implementation-deficit" (OECD. Public Governance and Territorial Development Directorate 2009, 7) of ethics management at the organizational level in taking into account "all instruments, factors and actors that influence the integrity of the members of an organization" (OECD. Public Governance and Territorial Development Directorate 2009, 9) and advocates especially to find a balance between the high-road and low-road approaches.

A general remark should be made regarding the OECD's overall interest in matters of corruption and ethics before trying to set up a concept of administrative ethics. Thus far, the focus has been put on PUMA and GOV, but other committees, directorates and groups have been dealing with these broad issues. The most important example is the Working Group on Bribery in International Business Transactions. It was created to monitor the implementation of the OECD Anti-Bribery Convention signed in 1997 and to support the fight against corruption of foreign public officials in international business.

There are two reasons why these initiatives are not taken into account for this study. The first one is the fact that activities concerning public-service ethics and corruption in business have been "fundamentally separate" (interviewee OECD1) for a long time due to the organization of work within the OECD. It was only recently that efforts were made to coordinate the different directorates through a more integrated approach with the CleanGovBiz initiative $e^{7}$ launched in 2011. Apart from this organizational aspect, a central difference lies also in PUMA's initial focus on the "positive side" (OECD. Public Management Service 1996, 6) of ethics given its direct relationship with the movement of managerial reform. In addition to a continuous attention to conflicts of interests and corruption problems, the work on public ethics has also stressed the promotion of public servants' good conduct. This goal has thus implied to resort to non-binding ethics management tools instead of focusing mainly on law enforcement as privileged in the Anti-Corruption program.

7 See Organization for Economic Cooperation and Development, The CleanGovBiz Initiative. Available at http://www.oecd.org/cleangovbiz/ (last accessed 30 January 2016). 


\subsection{The two key dimensions of administrative ethics}

This brief overview of the OECD's activities on public ethics in the past twenty years is obviously limited. Many other elements, factors and actors should be recalled in order to get a more precise and comprehensive explanation of the work done by the international organization on this topic. Nonetheless, it is believed to be far sufficient as regards the main goal of this article, namely identifying and conceptualizing the central features of administrative ethics in the context of publicmanagement reforms.

By and large, it seems necessary to distinguish between two levels of concern about the ethical issue in public administration, each level being associated to a key dimension of the theoretical concept of administrative ethics proposed. These two key dimensions are the following:

- the managerial dimension, which focuses on the management of civil servants' daily behaviors and practices in the process of policy-making and policy implementation. It relies on both the compliance-based and integrity-based approaches to ethics management, i.e. laws, rules, norms and all binding and nonbinding instruments which govern conducts in public administration;

- the normative dimension, which refers to the substantive content of administrative ethics, i.e. the normative framework incorporating the core principles and values, especially the political and moral ones, which define civil servants' professional identities and guide their specific missions and goals within the democratic system. This dimension is concerned with the legitimacy of the civil service and thus citizens' trust in government.

Several comments need to be made just after this quick presentation. On the one hand, it is possible to single out three degrees of analysis applying to each dimension, namely: the overall civil service, the organizational level and the individual case level. Let's give several examples combining the two dimensions together at these different levels. A first one can refer to the core principles (the public interest, impartiality, integrity, equality etc.) applying to the whole civil service and expressed in a law, e.g. the general statute of civil service in France. Then, it is possible to stress an organization's particular values, which are to be summarized in a specific statement or binding code of conduct. And finally, at the individual level, any public servant might have to sort out conflicting values, norms or rules so as to make a decision and act in the most appropriate way in given circumstances.

On the other hand, these two dimensions of administrative ethics prove to be strongly intertwined, and both are considered essential to characterize it. The normative dimension is here particularly essential because it sheds light on the broad normative framework which legitimates any kind of public action or behavior and thus any management system set up in public administration. This framework usually has the same basis in Western countries, which the OECD summarizes this 
way: "the fundamental mission of the public service is ... serving the public interest" (OECD 2000, 28). It is, however, worth pointing out that the normative dimension avoids defining beforehand which values are relevant or not (Huberts 2014). Its main function consists in highlighting the public interest as the core normative specificity of administrative ethics in democratic states.

Indeed, the common reference to the public interest does not mean that all these countries would share the same public values or, more probably, would rank them in the exact same order. This question is not only context-related but also very complex insofar as the priority attached to one or several public values may differ greatly depending on particular situations, and conflicts of values may therefore be frequent. Nonetheless, the great probability of ethical dilemmas justifies, at least to a certain extent, complementing detailed rules and enforcement mechanisms with incentive tools like statements of values, training, ethics advisers etc. The latter aim rather at stimulating and supporting public servants' ethical reflection and autonomous judgment to cope with unexpected or ambiguous situations (Maesschalck 2005).

Finally, the normative and managerial dimensions turn out to be reinforcing each other. They have to be taken into account in a simultaneous way to provide public-administration ethics with its proper meaning, as shown in detail in scheme 1. The compliance-based approach to ethics management (referred to only as "compliance" in the scheme) appears as a top-down implementation of the normative framework, i.e. all fundamental principles and values, in particular the political and moral ones like, for example, the public interest, the rule of law, neutrality, probity etc. They are primarily, but not exclusively, embodied by the constitutional and legal frameworks of any democratic system.

In a complementary manner, the integrity-based approach (symbolized by "integrity" in the scheme) starts from practical behaviors to determine and justify, in a bottom-up perspective, what are the core values and principles to prevail or the rules and norms to be applied depending on specific circumstances. As a result, practical reality represents a point of departure from which to assess and clarify the normative content of administrative ethics, especially when values, norms or even rules are conflicting or missing. Following the three degrees mentioned before, this evaluation may be carried out at different levels by the civil servant, the leaders of his organization or the relevant court when concerning the overall civil service. 


\section{Scheme 1}

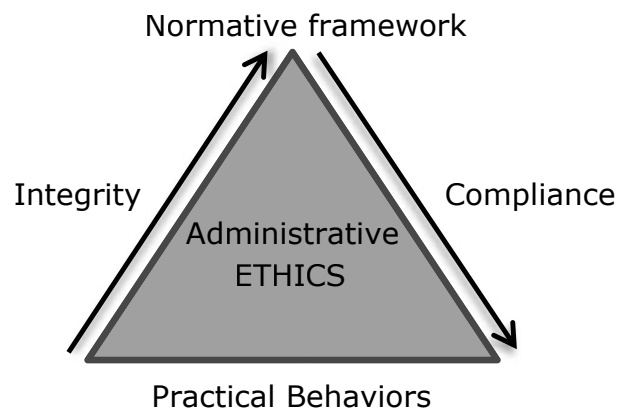

All these reflections and the concept of administrative ethics put forward in this article may seem to be quite obvious and not breaking new grounds. It has to be acknowledged that many scholars in administrative ethics do take into account these two typical dimensions but only to some extent. For example, John Rohr complemented his work on ethics management with reflections about the political regime values and "the values of American people" (Rohr 1976, 399) serving as the foundation for the US civil service. A more recent example is the distinction made by Jeroen Maesschalck between the "ethical" and "organizational" dimensions (Maesschalck 2005, 28) displayed by any ethical issue in an organization. Although this distinction seems to mesh with the concept of administrative ethics detailed above, there is still one major difference found in the attention paid to the normative dimension. Indeed, the analysis of Maesschalck deals in the end exclusively with the managerial side. If he is well aware of the moral aspect lying at the core of ethical dilemmas, the emphasis is put mainly on the way to handle them thanks to ethical decision-making.

The concept presented in this article tries to shed light in a more comprehensive and explicit way on the specific challenges related to ethics in public administration. The normative dimension appears all the more important as it distinguishes administrative ethics from other ethical theories, especially business ethics. It is indeed interesting to remark that the integrity-based approach privileged by the OECD at the beginning was actually congruent with the introduction of ethics codes and value statements in many Anglo-Saxon business firms since the late 1970s. Their idea was to replace formal controls with greater autonomy allowed to managers (Peters and Waterman 1982) so as to lower control costs and increase economic performance (Boltanski and Chiapello 2011), but also to escape from state regulation in showing their ability to self-regulate themselves.

On the contrary, the growing priority attached to managerial values like the three "E's" (economy, efficiency and effectiveness) in OECD countries has proved to be a more problematic ethical challenge insofar as it has tended to question the 
identity of the civil service and its legitimate role in democracy. On a theoretical plane, it seems therefore that the clash between public-administration ethics and new public management really breaks out at the normative level. However, there is no contradiction, at least formal, between the two at the managerial level where ethics is simply understood as a kind of management tool.

\section{Ethical challenges of the Canadian and French public administration in a context of NPM reforms: a comparison}

The following part is going to test the theoretical as well as methodological utility of the concept of administrative ethics devised previously. For that purpose, it relies on a comparison between the Canadian and French governments' respective ways to conceive and deal with the ethical issue in a context of managerial reforms. Using the two dimensions as an analytical grid, the study tackles each of them separately even though they are strongly intertwined, as already mentioned. It starts with the managerial one before moving to the normative one and combines the presentation of major examples from Canada and France which are related to every dimension.

It must be mentioned before starting that the focus is here exclusively on the Canadian federal level and the French state civil service. In addition, there are no specific distinctions made either between official initiatives and their effective implementation, or between the different positions held by civil servants (high level, middle level and the rank-and-file level) and between the corps, i.e. specific "groupings of officials" (Bezes and Jeannot 2011, 191) in the French civil service. One has nonetheless to bear in mind these blind spots when reflecting more heavily on the topic, especially for the problem of politicization. The latter proves to touch much more top public officials in both countries due to traditions of political appointments (Dwivedi and Halligan 2003, 156; Bezes and Jeannot 2011, 198).

Besides, the time period covered runs mostly from the mid-1980s up to the late 2000s so as to give an historical overview ${ }^{8}$ about the ways both countries have evolved in this matter. However, it is loosely delimited to accommodating the particularities of national pathways in terms of administrative ethics and, more generally, public-management reforms. It is interesting to remark in this regard the apparent gap between the two countries. Indeed, Canada began to devote official attention to management in the public service in the early 1960s with the establishment of the "Glassco Royal Commission on Government Organization" (Dwivedi and Halligan 2003, 151), whereas the French public administration was quite reluctant towards managerial ideas up until the 1980s (Bezes 2009).

8 The comparison leaves aside to some extent developments of public-administration ethics in Canada and France since the 2010s. The reasons for this are twofold: first, there are fewer archive documents available for the most recent period; second, this research is still in progress, especially regarding France's very last initiatives to update her ethics infrastructure. 
This opposition can nonetheless be questioned due to the paradoxical fact that Canada has been particularly "slow to incorporate and institutionalize" (Dwivedi and Halligan 2003, 148) management reforms. The latter really took off at the national level with Prime Minister Brian Mulroney in office in the mid-1980s (Dwivedi and Halligan 2003, 151). It was nearly at the same period in France, more precisely in 1989, that the socialist Prime Minister Michel Rocard launched a managerial program of state reform entitled "Public Service Renewal" (Renouveau du service public) (Bezes and Jeannot 2011, 201). It was the point of departure for a series of clearly NPM-oriented reform initiatives throughout the 1990s (Bezes 2009, 377). This broad context being recalled, it is now time to examine more specifically how the ethical issue has developed in the two states.

\subsection{The managerial dimension of administrative ethics: the difficult emergence of a high-road approach}

\subsubsection{Canada}

The Canadian government's concern regarding the management of public servants' behaviors started with the publication in 1984 of the Starr-Sharp report on conflict of interest (Boisvert 2011b, 55). This first initiative paved the way for a continuous series of conflict-of-interest policies in the Canadian federal civil service, based mainly on compliance with detailed rules. For example, just one year later the Mulroney government adopted a "Conflict of Interest and PostEmployment Code for Public Office Holders" (Kernaghan 1996, 7). An "Ethics Counsellor" (Kernaghan 1996, 9) was also appointed ten years after the report to monitor, among other things, the enforcement of the code. This latter position was eventually replaced in 2004 by an independent Conflict of Interest and Ethics Commissioner (Boisvert 2011b, 85).

But parallel to this development, other initiatives focusing on a high-road approach to ethics have emerged since the late 1980s and have taken the form primarily of attempts to define statements of public values. A good example is the establishment in 1987 of a "Committee on Governing Values" in charge of "identifying those values which are common across the Public Service" (Canada 1987, 4).

The "Public Service 2000" project launched in 1989 showed also explicitly the link between the stress on public servants' ethics and the managerial movement in the federal public service. It consisted in several working groups of senior officials mobilized to set up priorities for an ambitious program of reform in public administration. Their goal was to promote a new client-oriented culture instead of the traditional command and control bureaucracy (Dwivedi and Halligan 2003, 164). Special importance was given to "the individual responsibility and to professionalism" (Canada 1990,2) of the public service's members in accordance with the broad "new 'guide and encourage' ... approach to management" put forward (Dwivedi and Halligan 2003, 165). 
The development of a consistent integrity-based approach nonetheless reached a turning point with the Task Force on Public Service Ethics and Values, initially created in 1995 as a study team by the Canadian Center for Management Development (CCMD). Chaired by John Tait, the deputy minister of Justice, the Task Force strived to overcome the relative failure of previous values exercises due to a remaining gap between good intentions and real practices within the federal public service. For that purpose, it chose to resort to an "inductive approach" (interviewee Canada1), based on a lucid discussion of concrete problems faced by public servants, what it called an "honest dialogue" (Tait 1996, 3).

The final report, entitled A Strong Foundation, pointed out for the first time the need to tackle "conflicts between values" (Tait 1996, 2) arising in public administration. It acknowledged that dilemmas were triggered by the new priority attached to managerial values at the expense of other important public values. The report thus called for a largely open discussion on this topic throughout the federal public service following its specific approach. Moreover, it advocated to complement formal codes and rules often too limited in these matters with training and tools for civil servants to be able to handle ethical dilemmas.

The activities of the Task Force created a momentum for integrity-based measures in the late 1990s and early 2000s. Two "Co-Champions of Values and Ethics in the Public Service" (Canada 2001, 1) were appointed to pursue activities and to promote dialogue on values and ethics in the federal public administration through a "case-study approach" (Canada 2001, 1) devised in two specific handbooks. The Values and Ethics Office of the Treasury Board of Canada was also established in 1999 in order to set up the conditions for a values-based management within the public service (Kernaghan 2007, 26).

However, a series of major scandals breaking out in the first half of the 2000s have finally turned the tide towards re-emphasizing the issue of conflict of interest and the strict compliance with rules. One good example among others of this dynamic is the Federal Accountability Act passed in 2006, which encompasses all the codes and standards regarding conflict of interest, whistleblowing, post-employment and lobbying in one integrated law (Boisvert 2011b, 64). Despite this clear tendency witnessed since the mid-2000s, it seems nonetheless that the discussion of values and ethics based on the dialogical model put forward by the Tait report remains deeply rooted in the Canadian public service. The distinction between compliance-based and integrity-based approaches to ethics management is largely acknowledged as well (interviewee Canada2).

\subsubsection{France}

The French way of dealing with civil servants' ethics usually privileges a compliance-based approach. Indeed, it draws from the traditional conception of the state as the guardian both of the general will expressed by the law and the unity of soci- 
ety, justifying the use of exclusive prerogatives. The civil service is thus based on a "specific administrative law" (Bezes and Jeannot 2011, 186), separate from common law, and a merit and career system. Established in 1946, the latter implies that independent and impartial civil servants are expected to serve the public interest and the principles of equality, continuity and adaptability lying at the core of the French concept of service public.

The principle of hierarchy, which is regarded as an "operational translation" (Chambon and Gaspon 1996, 49) of the law and represents a major basic principle of the civil service, strongly shapes ethics in public administration. The very first ethical requirement for a French civil servant is to obey and abide by the orders of his superiors unless they are against the law and the public interest. Therefore, public-administration ethics amounts in the first place to the exercise by the hierarchy of a disciplinary power sanctioning civil servants' bad behaviors.

This formal view limits the ethics of civil servants to the respect of professional obligations and conveys an abstract and absolute vision of the public interest. Coupled with the old and largely accepted tradition of cumulating powers and functions (Mény 1992, 20), it explains to a certain extent that conflicts of interest regarding public officials have been overlooked for a long time in France. A change nonetheless began in the mid-1980s with a series of laws completing the general statute of 1983. They stated a list of incompatibility between public and private functions to face the increasing phenomenon of pantouflage, i.e. civil servants leaving office for the private sector.

The movement intensified in the mid-1990s with the creation of an Ethics Commission for each specific civil service, which turned into one commission for all civil servants in 2007. ${ }^{9}$ It is in charge of issuing opinions on potential conflict of interest concerning a civil servant leaving office for the private sector or cumulating activities in both spheres (Chambon and Gaspon 1996, 80). More generally, the Central Service for the Prevention of Corruption (Service Central de Prévention de la Corruption) was established in 1993 within the Ministry of Justice, in the aftermath of the specialized Bouchery commission on this topic (Lascoumes 1999, 131), to collect and centralize data, give advice to authorities and raise awareness about corruption in France while also taking part in international cooperation and action. ${ }^{10}$

Apart from issues of conflicts of interest and corruption, the attention to civil servants' ethics increased in the first half of the 1990s in close relation to the overall

9 See Commission de déontologie, Missions, published on the Ministry of Civil Service's website on 4 August 2011. Available at http://www.fonction-publique.gouv.fr/missions (last accessed 11 February 2016).

10 See the Central Service for the Prevention of Corruption, published on the Ministry of Justice's website on 6 December 2012. Available at http://www.justice.gouv.fr/multilinguisme-12198/ english-12200/the-central-service-for-the-prevention-of-corruption-24860.html (last accessed 11 February 2016). 
process of state modernization set up by the Public Service Renewal program. The activities of the General Planning Commission (Commissariat Général du Plan) in particular, or the Picq mission on the state's responsibilities and organization (Mission sur les responsabilités et l'organisation de l'Etat), stressed continuously the "crisis of effectiveness" (France. Commissariat Général du Plan 1993, 131) and the need to improve the quality of public-service delivery to citizens in accordance with NPM ideas (Bezes 2009, 373-377).

For that purpose, the major public reports put the emphasis on devolving power to more autonomous administrative services (France. Commissariat Général du Plan 1993, 133) and more responsible civil servants. Responsibility was regarded by reformers as a kind of "monitored trust", which allowed more discretion to civil servants in betting on their "capacity and integrity" (France. Commissariat Général du Plan 1989, 48). In a surprising way, this movement tended both to reinforce ethics rules guaranteeing the neutrality and impartiality of the civil service (France. Commissariat Général du Plan 1989, 44; 1993, 59) and to put forward ethics charters which would specify traditional and new principles guiding the work of public servants (Picq 1994, 127).

This focus on responsibility and broad charters may be seen to a certain extent as the beginning of an integrity-based approach to ethics in the French public administration. Indeed, the responsible civil servant was regarded in the early 1990s as the one able to define and adapt the changing notion of the public interest to the reality (France. Commissariat Général du Plan 1993, 29) in order to ensure the effectiveness of public services and thus guarantee citizens' trust in government (France. Commissariat Général du Plan 1989, 34-35). A high-road perspective in terms of ethics management appeared then to the proponents of state reform as a way to reconcile legality and effectiveness (Chambon and Gaspon 1996, 6) and as a "powerful lever" to finally modernize public administration (France. Commissariat Général du Plan 1993, 60).

Despite these initiatives, it must be noted that public-administration ethics in France has remained largely insensitive to this perspective up until the late 2000s. There has been an important increase since then in the production of soft law mechanisms in public organizations, like codes and charters of ethics associated with ethics advisers giving recommendations to guide the practices of their members (Pêcheur 2013, 4). The importance to develop a new ethical culture was a key recommendation of the commission established in 2010 to reflect on the prevention of conflict of interest in public life (Sauvé et al. 2011, 95). Some of its recommendations have been taken up in the draft law on civil servants' ethics like, for example, the settlement of "ethics advisers" (France. Assemblée Nationale 2015, 21).

Another good example of this dynamic is the enactment in 2011 by the Council of State of a Charter of ethics for the members of the administrative jurisdic- 
tion. ${ }^{11}$ It is all the more interesting that the French supreme administrative court was very much reluctant in the 1980s and 1990s towards this kind of documents giving additional written specifications of rules due to their encroachment on its jurisprudential activity (Bezes 2009, 248). Besides, the Council of State has made efforts recently to adapt the definition of soft law mechanisms to its judicial doctrine, based on the paramount role of hard law and the respect of legal security for citizens (France. Conseil d'Etat 2013).

To conclude this brief overview, it is worth pointing out the ambiguous development of public-administration ethics since the mid-2000s. Indeed, the traditional French term déontologie (ethics) and the reference to law as being its main foundation (Vigouroux 2006, 17) remain largely shared by specialists in the field who are, most of the time, administrative lawyers and judges. But paradoxically enough, some of them have strived to distinguish, more or less implicitly, the meaning of ethics from the ideas of discipline and sanction (Vigouroux 2006, 27; Truchet $2010,2129)$ to emphasize the more positive and ambitious empowering approach to ethics management. If some commentators have raised doubts (Niquège 2014, 281 ) about the claim that it is a "misinterpretation" (Vigouroux 2006, 25) to associate ethics with discipline, this tendency sheds light on some of the main evolutions regarding public-administrative ethics currently occurring in France.

\subsection{The normative dimension of administrative ethics: debates around core public values}

\subsubsection{Canada}

Choices regarding the most suitable ways to govern public servants' conducts, especially in a period of managerial reforms, have been related both in Canada and France to complementary debates on the core principles and values to defend and the type of civil-service system to promote.

The Canadian public service is probably the institution in the OECD zone which has developed the most intense and accurate reflection on public-administration values. This is shown by the usual distinction made between values and ethics since the activities of the Task Force on Public Service Values and Ethics in the mid-1990s. As already mentioned, several initiatives were launched in the late-1980s to find out the specific values of the federal public service. The principal goal of the "Committee on Governing Values" was, for example, to "revitalize the Public Service" (Canada 1987, 11) through the rediscovery of shared values. It is important to stress nonetheless that the latter were in this case supposed to

11 See Charte de déontologie des membres de la juridiction administrative, published on the Council of State's website on 12 January 2012. Available at http://www.conseil-etat.fr/Actualites/Communiques/Charte-de-deontologie-des-membres-de-la-juridiction-administrative-edition-2011 (last accessed 11 February 2016). 
serve as a "means for change" (Canada 1987, 17) to improve productivity and the quality of public services.

The interest for values was again mainly due to the focus on them in the private sector as a key factor of successful enterprises (interviewee Canada1). Moreover, different initiatives of NPM reform at the time tended to deepen the idea of a blurring divide between the public and private sectors in favor of the latter. The final White Paper of Public Service 2000 put for example a great emphasis on managerial values like "service to the public, innovation, empowerment of employees" (Dwivedi and Halligan 2003, 164). Similarly, the "Program Review exercise" (Kelly 2000, 73), set up in 1994 to curb the financial and budgetary crisis of the Canadian state, triggered a huge movement of downsizing in the public sector (Dwivedi and Halligan 2003, 167) and put forward the principle of "employability" (interviewee Canada1) at the expense of career public servants.

It is in this broader context that the study group chaired by John Tait started its work. The explicit purpose was not only to respond to potential threats on the very identity of the federal public service but also to clarify some ambiguities concerning the role of values. Indeed, the previous exercises principally looked at values as a management tool useful to get rid of centralized and constraining rules in public administration. But according to a former member of the Task Force, the very first question guiding the activities was to figure out which values could define what it meant to be a public service (interviewee Canada1), and after that to concentrate on the rules able to translate them in practice.

Hence the necessity to focus separately on the values and ethics of the public service whose respective meaning may be roughly summarized in the following way: "values is who we are, ethics is what we do" (interviewee Canada1). The group questioned heavily the idea imported from the private sector that values could replace rules and claimed that:

it is also important not to lose sight of the important role that some rules will always play in public administration, as means to ensure democratic will and to preserve the legitimacy of government (Tait 1996, 41).

It must be noted here that the confusion regarding values is well identified and overcome when one considers the analytical grid presented earlier in this article. The major problem in this case stemmed from the fact that the normative dimension, i.e. the substantive content of administrative ethics, was completely overlooked by NPM-type reforms. More precisely, the latter regarded values either as a mere management tool or pushed for managerial values instead of taking into account the paramount goal of public servants in democracy, i.e. serving the public interest. 
The activities of the Tait group were not in complete opposition to NPM initiatives, though. It tried rather to strike a balance between public management and traditional public administration in asserting that:

a synthesis of old and new values is both possible and necessary, and that together they will help to create an even stronger culture of public service (Tait 1996, 37).

However, the final report, entitled A Strong Foundation, did shed light on the hierarchy between values existing in the federal public service. Among the four different categories of core values identified, what it referred to as "democratic values, professional values, ethical values, and people values" (Tait 1996, 53), the democratic ones were stressed as "the most important of all and the one that provides the foundation for all the rest" (Tait 1996, 53) insofar as:

The Study Team has rediscovered that the most important defining factor for the role and values of the public service is its democratic mission: helping ministers, under law and the Constitution, to serve the common good (Tait 1996, 17).

The adoption in 2003 of the first Values and Ethics Code for the Public Sector stating this set of core public values (Canada 2003, 7-10) was finally an official recognition of them as being the normative framework guiding all Canadian public servants. It was also confirmed by the slightly revised version of the new code issued in 2011, which took up most of these values (Canada 2011, 3-4).

\subsubsection{France}

Contrary to the debates in Canada, there was a continuous agreement in the 1990s in France about the core values of public administration despite the more intense introduction of management reforms. One of the main reasons lay in the constant consolidation of the traditional features of public administration during the previous decade with a socialist and communist government in power. It is particularly important to recall here that the adoption in 1983 of a general statute to the three civil services (state, local and hospital) brought about a significant strengthening of the career civil service (Bezes 2009, 226). This act of "rationalization and extension" (Bezes and Jeannot 2011, 192) of the existing statutory laws reinforced, for example, the principle of hierarchy, which was officially included in the general statute. ${ }^{12}$

Such a movement has then influenced many public-management initiatives developed since the late 1980s. It produced a hybrid trajectory of state reform, encompassing both the promotion of new economic ideas and the defense of classic administrative values (Bezes 2009, 438). Some of the official reports published during this period clearly showed this French characteristic way of dealing with

12 See article 28 of the law of 13 July 1983 related to civil servants' rights and obligations (loi du 13 juillet 1983 portant droits et obligations des fonctionnaires). 
NPM reforms throughout the 1990s. For example, the study on the improvement of state effectiveness conducted by the General Planning Commission claimed that the statute of the civil service was "a valuable asset" for the policy of modernization (France. Commissariat Général du Plan 1989, 91). In a similar vein, a following report pointed out that "equality, neutrality, continuity" remained the core public values, even though transparency and responsibility had to be added to the list (France. Commissariat Général du Plan 1993, 59). In addition, the Council of State reasserted in its 1999 report that, despite increasing criticisms, the public interest was still "the keystone of public action of which it determines the goal and founds the legitimacy" (France. Conseil d'Etat 1999, 245).

Unlike Canada and other OECD countries during the same period, the French reformers finally kept emphasizing the specificity of the public sector compared to the private one. However, the situation began to change in the early 2000s, given a new series of management standards more systematically affecting public administration. The main reform was the adoption on 1 August 2001 of the Organic Act on Budget Legislation (Loi organique relative aux lois de finances), which created a result-based and performance-oriented budgetary process fully implemented since 2006 (Bezes and Jeannot 2011, 204). The latter paved the way for the devolution of powers in favor of administrative services, performance measurement and a greater individualization of civil servants' careers.

This dynamic was deepened by the General Review of Public Policy (Révision générale des politiques publiques) launched in 2007. It looked for major cutbacks in personnel and public expenditures while promoting mobility and fixed-term contracts within the public sector. This global movement has provoked "destabilizing effects" (Bezes and Jeannot 2011, 205) on the traditional model of civil service, insofar as it put forward a logic of employability challenging the statute and career system. It has thus led to questioning the historical identity of the French civil service in a similar way to what happened in Canada during the 1990s.

As a result, quite unusual debates about public values (interviewee France1) and especially the need to update and adapt them to the evolving society emerged in the late 2000s. The "national conference on values, missions and jobs of the public service and civil service"13 (Silicani 2008, 9) was the most significant example in this regard. The six-month activities, gathering politicians, civil servants, scholars, experts and citizens from October 2007 to April 2008, highlighted three categories of fundamental values for the civil service, namely "republican values" (liberty, equality, fraternity etc.), "professional values" (legality, effectiveness, adaptability, continuity, probity, exemplarity etc.) and "human values" (commitment, respect, solidarity etc.) (Silicani 2008, 58-69).

13 Conférence nationale sur les valeurs, les missions et les métiers du service public et de la fonction publique. 
Apart from the great diversity of values referred to, the final White Paper advocated for a "synthesis" (Silicani 2008, 57) between traditional and modern values. Another major contribution of the conference was to concentrate on difficulties to implement and reconcile these potentially conflicting values in daily practice (Silicani 2008, 74). For that purpose, the White Paper recommended to adopt a non-binding and incentive charter of civil-service values which would be less constraining, more adaptable to particular circumstances and could evolve (Silicani 2008, 78-80).

It is crucial to note that, contrary to the situation in the 1990s, the missions and goals of the civil service were considered at the time not clear and precise enough to guide the overall process of administrative reform and the improvement of effectiveness (Silicani 2008, 84). That's why reformers and specialists in administrative ethics (Vigouroux 2006, 5) have recently expressed the need to emphasize key public values which are not formally found in statutory laws (Niquège 2014, 284). This effort has been conceived both as a way to stress the persistent professional morality and identity of the French civil service and as a visible and symbolic response (Niquège 2014,287) to more pressing expectations and demands from citizens so as to strengthen public trust in government.

The draft law related to civil servants' ethics, rights and obligations adopted in October 2015 by the National Assembly meets this concern in proposing, for the first time, to mention explicitly in the general statute the core principles and values applying to all civil servants. These values are "dignity, impartiality, integrity and probity" (France. Assemblée Nationale 2015, 3) as well as neutrality and the principle of laïcité (secularism). In spite of this innovation, it must be underlined that not only the particular values referred to but also the choice made by the current socialist government to express them in a law remain in synch with the French traditional approach to public administration.

\section{Conclusion}

This article puts forward a theoretical concept of administrative ethics in order to shed light on the central features of the ethical issue in public administration, and especially in the context of NPM reforms. Devised from an historical review of the OECD activities on public ethics and integrity, this concept encompasses two major dimensions which are strongly intertwined. On the one hand, the managerial dimension focuses on the management of civil servants' behaviors in combining the compliance-based and integrity-based approaches. On the other hand, the normative dimension emphasizes the core principles and values which embody the normative framework defining the specific identity and legitimate mission of the civil service in democracy. 
Used then as an analytical grid to compare the Canadian and French interest in administrative ethics since the implementation of public-management reforms, this concept proves to be relevant to stress the diverse ethical challenges faced by these countries. It is particularly useful to distinguish between the managerial and normative dimensions in order to be able to sort out some ambiguities about the ethical issue in both cases. It helps, for example, to overcome the confusion about the meaning attached to values in Canada, which have been regarded either as a management tool or a normative standard. In the French case, this concept makes it possible to clarify recent evolutions in the way to perceive and deal with administrative ethics, e.g. the new focus on incentive instruments and the discussion of core values, which are not always clearly stated and remain hidden behind the historical reference to déontologie.

The comparison of Canada and France's pathways of managerial modernization reveals some of the proper characteristics of each civil service, like the rapid but cautious adoption of NPM ideas (Dwivedi and Halligan 2003, 70-71) by the former or the strong influence of administrative law for the latter. And yet, one crucial similarity at least must be outlined concerning the general creation of "hybrid administrative systems" (Christensen 2012, 2) which incorporate elements from traditional public administration and new public management. This tendency is particularly visible when focusing on the increasing comprehensive approach displayed to tackle the ethics of civil servants, not only at the managerial level with a combination of compliance-based and integrity-based strategies, but also at the normative level with the search for a synthesis between "old" and "new" public values.

Finally, such a movement shows that administrative ethics represents a complex issue, which includes problems of corruption and wrongdoing but goes also far beyond. Indeed, it seeks to promote the most appropriate behaviors of civil servants on a daily basis in order to reinforce citizens' trust in government and thus ensure its ongoing legitimacy. However, it is important to keep bearing in mind the importance of context when tackling administrative ethics. This article draws insights mainly from the OECD area, but further comparative researches would be needed to highlight in a more thorough manner the multiple ethical challenges weighing on public administration in diverse environments and the many concrete ways to deal with them. For example, the discussions engaged about the specific situation of Central and Eastern European countries in this matter during the $9^{\text {th }}$ Trans-European Dialogue held in Ljubljana (Slovenia) on 4-5 February 2016 offered interesting clues to improve the concept of public-administration ethics put forward and to develop a better understanding of this crucial issue. 


\section{References}

Bezes, Philippe. 2009. Réinventer l'Etat. Les réformes de ladministration française (1962-2008). Paris: Presses universitaires de France. Collection le lien social.

Bezes, Philippe and Gilles Jeannot. 2011. “The Development and Current Features of the French Civil Service System." In Frits Van Der Meer (ed.). Civil Service Systems in Western Europe. $2^{\text {nd }}$ ed. Cheltenham and Northampton: Edward Elgar, 56-62.

Boisvert, Yves (ed.). 2011a. Ethique et gouvernance publique: Principes, enjeux et défis. Montréal: Liber.

Boisvert, Yves. 2011b. L'institutionnalisation de l'éthique gouvernementale: Quelle place pour l'éthique? Québec: Presses de l'Université du Québec.

Boisvert, Yves, Magalie Jutras, Georges A. Legault, Allison Marchildon and Louis Côté. 2003. Petit manuel déthique appliquée à la gestion publique. Montréal: Liber.

Boltanski, Luc and Eve Chiapello. 2011. Le nouvel esprit du capitalisme. $2^{\text {nd }}$ ed. Paris: Gallimard. Collection Tel.

Canada. 1987. Governing Values: Report of the Committee on Governing Values. Ottawa: Ministry of Supply and Services Canada.

Canada. 1990. Fonction publique 2000: Rapport du groupe détude sur la formation et le perfectionnement. Ottawa: Conseil du Trésor. 23 juillet.

Canada. 2001. Building on a Strong Foundation - The Dialogue Continues volume II. Ottawa: Canadian Centre for Management Development.

Canada. 2003. Values and Ethics Code for the Public Sector. Ottawa: Treasury Board of Canada Secretariat.

Canada. 2011. Values and Ethics Code for the Public Sector. Ottawa: Treasury Board of Canada Secretariat.

Chambon, François and Olivier Gaspon. 1996. La déontologie administrative. Paris: Librairie générale de droit et de jurisprudence.

Christensen, Tom. 2012. "Post-NPM and Changing Public Governance." Meiji Journal of Political Science and Economics 1, 1-11.

Cooper, Terry. 2001. "The Emergence of Administrative Ethics as a Field of Study in the United States." In Terry Cooper (ed.). Handbook of Administrative Ethics. $2^{\text {nd }}$ ed. New York: Marcel Dekker Inc., 1-36.

Cox III, Raymond (ed.). 2009. Ethics and Integrity in Public Administration: Concepts and Cases. New York: ME Sharpe. 
De Graaf, Gjalt and Zeger Van Der Wal. 2009. "Introduction: The Need for Methodological Rigor and Diversity in Administrative Ethics." Public Integrity $11(1), 5-8$.

De Graaf, Gjalt and Zeger Van Der Wal. 2010. "Managing Conflicting Public Values: Governing with Integrity and Effectiveness." The American Review of Public Administration 40(6), 623-630.

De Graaf, Gjalt and Hester Paanakker. 2015. "Good Governance: Performance Values and Procedural Values in Conflict." The American Review of Public Administration 45(6), 635-652.

Dwivedi, O. P. and John Halligan. 2003. "The Canadian Public Service: Balancing Values and Management." In John Halligan (ed.). Civil Service Systems in Anglo-American Countries. Cheltenham and Northampton: Edward Elgar, 148-173.

France. Commissariat Général du Plan. 1989. Le pari de la responsabilité. Rapport de la commission Efficacité de l'Etat présidée par François de Closets. Paris: La Documentation Française.

France. Commissariat Général du Plan. 1993. Pour un Etat stratège, garant de l'intérêt général. Rapport de la commission Etat, administration et services publics de l'an 2000 présidée par Christian Blanc. Paris: La Documentation Française.

France. Conseil d'Etat. 1999. L'intérêt général. Rapport public 1999. Paris: La Documentation Française. Etudes et documents no. 50.

France. Conseil d'Etat. 2013. Le droit souple. Etude annuelle 2013. Paris: La Documentation Française. Les rapports du Conseil d'Etat no. 64.

France. Assemblée Nationale. 2015. Projet de loi relatif à la déontologie et aux droits et obligations des fonctionnaires. Adopté par l'Assemblée Nationale en première lecture. Session ordinaire de 2015-2016, 7 octobre. Available at http://www.assemblee-nationale.fr/14/ta/ta0594.asp (last accessed 25 January 2016).

Hassenteufel, Patrick. 2005. "De la comparaison internationale à la comparaison transnationale: Les déplacements de la construction dobjets comparatifs en matière de politiques publiques." Revue française de science politique 55(1), $113-132$.

Hood, Christopher. 1991. “A Public Management for all Seasons?” Public Administration 69(1), 3-19.

Huberts, Leo. 2014. The Integrity of Governance. What It Is, What We Know, What Is Done, and Where To Go. New York: Palgrave MacMillan. IIAS Series: Governance and Public Management. 
Kelly, Joanne. 2000. "Budgeting and Program Review in Canada 1994-2000." Australian Journal of Public Administration 59(3), 72-78.

Kernaghan, Kenneth. 1996. The Ethics Era in Canadian Public Administration. Ottawa: Canadian Centre for Management Development. Research paper 19. June.

Kernaghan, Kenneth. 2007. Une vocation spéciale: valeurs, éthique et professionnalisme de la fonction publique. Ottawa: Agence de gestion des ressources humaines de la fonction publique du Canada.

Kickert, Walter (ed.). 2008. The Study of Public Management in Europe and the US: A Comparative Analysis of National Distinctiveness. New York: Routledge.

Kolthoff, Emile. 2007. Ethics and New Public Management: Empirical Research into the Effects of Businesslike Government on Ethics and Integrity. The Hague: BJU Legal Publishers.

Kolthoff, Emile, Leo Huberts and Hans Van Den Heuvel. 2007. "The Ethics of New Public Management: Is Integrity at Stake?" Public Administration Quarterly 30(4), 399-439.

Lascoumes, Pierre. 1999. Corruptions. Paris: Presses de Sciences Po.

Lynch, Cynthia E. and Thomas D. Lynch. 2011. "Public Sector Value and Virtue and the OECD." In Michiel S. De Vries and Pan Suk Kim (eds.). Value and Virtue in Public Administration: A Comparative Perspective. London: Palgrave Macmillan. IIAS Series: Governance and Public Management, 241-255.

Maesschalck, Jeroen. 2004. “The Impact of NPM Reforms on Public Servants' Ethics: Towards a Theory." Public Administration 82(2), 465-489.

Maesschalck, Jeroen. 2005. "Approaches to Ethics Management in the Public Sector: A Proposed Extension of the Compliance-Integrity Continuum." Public Integrity $7(1), 21-41$.

Mény, Yves. 1992. La corruption de la République. Paris: Fayard.

Menzel, Donald C. 2001. "Ethics Management in Public Organizations. What, Why and How?" In Terry Cooper (ed.). Handbook of Administrative Ethics. $2^{\text {nd }}$ ed. New York: Marcel Dekker Inc., 355-366.

Merrien, François-Xavier. 1999. "La Nouvelle Gestion Publique: un concept mythique." Lien social et Politiques 41, 95-103.

Niquège, Sylvain. 2014. "Discipline et déontologie: de l'art et des manières de faire corps." In Charles Fortier (ed.). Le statut général des fonctionnaires: trente ans, et après? Paris: Dalloz, 279-290.

OECD. 1995. Governance in Transition: Public Management Reforms in OECD Countries. Paris: OECD Publishing. 
OECD. 1996. Ethics in the Public Service: Current Issues and Practices. Paris: OECD Publishing. Public Management Occasional Papers 14.

OECD. 2000. Trust in Government: Ethics Measures in OECD Countries. Paris: OECD Publishing.

OECD. Public Management Service. 1994. Summary record of the $9^{\text {th }}$ meeting of the public management committee held at the Château de la Muette, Paris on 7-8 April. Paris. Drafted on 25 May and distributed on 3 August. PUMA/M(94)1.

OECD. Public Management Service. 1995. Meeting of senior officials from centres of government on the impacts of globalisation on policy making. Maintaining ethics in public service: the role of the centre. Meeting to be held at Eigtveds Pakhus, Copenhagen on 28-29 September. Paris. 22 August. PUMA/MPM(95)6.

OECD. Public Managenement Service. 1996. Summary record of the $14^{\text {th }}$ meeting of the public management committee on 30-31 October. Paris. Distributed on 5 December. PUMA/M(96)2.

OECD. Public Management Service. 1997. Realignment and public sector ethics: the neglected management problem in the new public administration. Paper written by Stuart Gilman for the Symposium "Ethics in the Public Sector: Challenges and Opportunities for OECD Countries" to be held at the OECD, Château de la Muette, Paris on 3-4 November 1997. Paris. Distributed on 6 October. PUMA/ETH(97)11.

OECD. Public Governance and Territorial Development Directorate. 2009. Towards a Sound Integrity Framework: Instruments, Processes, Structures and Conditions for Implementation. Paris. 23 April. GOV/PGC/GF(2009)1.

Ongaro, Edoardo. 2009. Public Management Reform and Modernization Trajectories of Administrative Change in Italy, France, Greece, Portugal and Spain. Cheltenham and Northampton: Edward Elgar.

Pal, Leslie. 2009. “The OECD and Global Public Management Reform.” Croatian Public Administration 9(4), 1057-1089.

Pal, Leslie. 2012. Frontiers of Governance. The OECD and Global Public Management Reform. London: Palgrave MacMillan.

Pêcheur, Bernard. 2013. Rapport à Monsieur le Premier ministre sur la fonction publique. Paris: La Documentation Française.

Peters, Tom and Robert Waterman. 1982. In Search of Excellence: Lessons from America's Best-Run Companies. New York: Harper \& Row.

Picq, Jean. 1994. L'Etat en France: Servir une nation ouverte sur le monde. Rapport de la mission sur les responsabilités et l'organisation de l'Etat. Paris: La Documentation Française. 
Pollitt, Christopher and Geert Bouckaert. 2011. Public Management Reform: A Comparative Analysis - New Public Management, Governance and The NeoWeberian State. $3^{\text {rd }}$ ed. Oxford: Oxford University Press.

Rohr, John. 1976. "The Study of Ethics in the PA Curriculum." Public Administration Review 36(4), 398-406.

Rohr, John. 1978. Ethics for Bureaucrats: An Essay on Law and Values. New York: Marcel Dekker Inc.

Sauvé, Jean-Marc, Didier Migaud and Jean-Claude Magendie. 2011. Pour une nouvelle déontologie de la vie publique. Rapport de la Commission de réflexion pour la prévention des conflits d'intérêts dans la vie publique. Paris: La Documentation Française.

Silicani, Jean-Ludovic. 2008. Livre blanc sur l'avenir de la fonction publique: faire des services publics et de la fonction publique des atouts pour la France. Paris: La Documentation française.

Tait, John. 1996. A Strong Foundation: Report of the Task Force on Public Service Values and Ethics. Ottawa: Canadian Centre for Management Development.

Truchet, Didier. 2010. "Le besoin de déontologie." AJDA 38, 2129.

Vigouroux, Christian. 2006. Déontologie des fonctions publiques. Paris: Dalloz.

Weber, Max. 1965. "L’objectivité de la connaissance dans les sciences et la politique sociales.” Essais sur la théorie de la science. Premier essai. Paris: Plon. no. 19. 